Supporting Information for Research Article:

\title{
Heterogeneity in Economic and Carbon Benefits of Electric Technology Vehicles in the U.S.
}

Ranjit R. Desai1 ${ }^{*}$, Roger B. Chen ${ }^{2}$, Eric Hittinger ${ }^{3}$, Eric Williams ${ }^{4}$

Corresponding Author: Ranjit R. Desai

*Email: rd6646@rit.edu

${ }^{1}$ Golisano Institute for Sustainability, Rochester Institute of Technology, Rochester, NY 14623.

Present Address: 190 Lomb Memorial Dr. Rochester, NY 14623.

${ }^{2}$ Department of Civil and Environmental Engineering, University of Hawaii, Manoa, Honolulu, HI 96822.

${ }^{3}$ Department of Public Policy, College of Liberal Arts, Rochester Institute of Technology, Rochester, NY 14623

${ }^{4}$ Golisano Institute for Sustainability, Rochester Institute of Technology, Rochester, NY 14623.

\section{List of Figures}

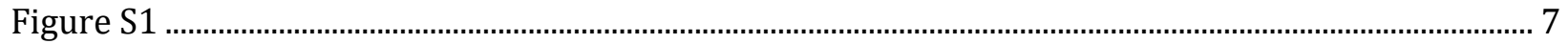

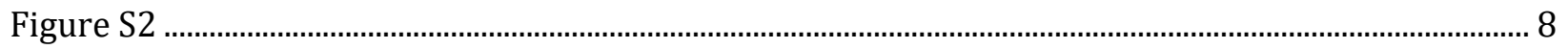

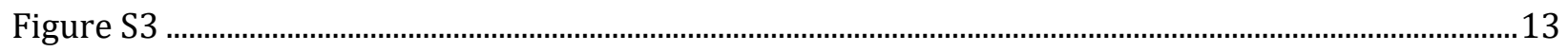

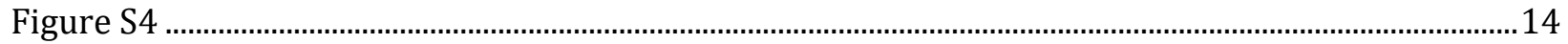

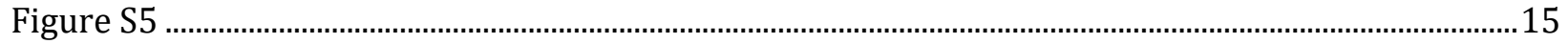

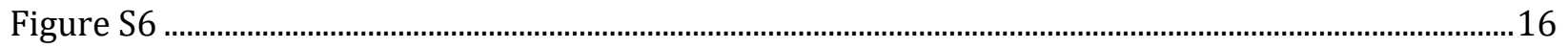

\section{List of Tables}

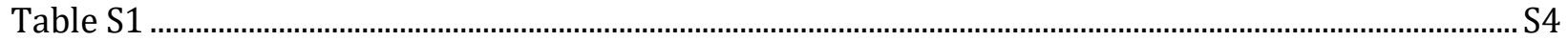

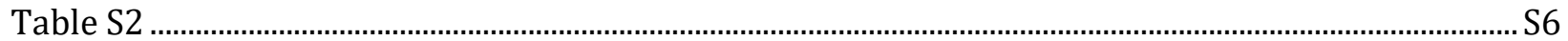

\section{Number of Pages: 18}

\section{Contents}

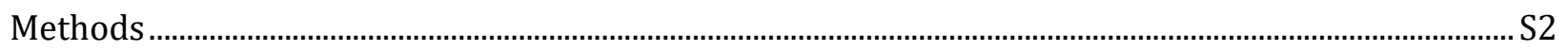

Defining Consumer Vehicle Options for Internal Combustion Engine and ETVs................................S2

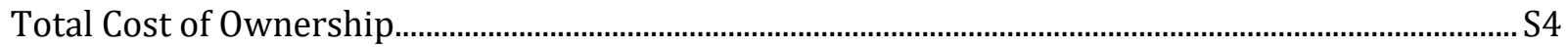

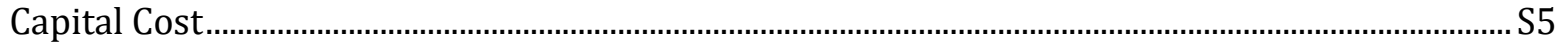

Calculation of Expected Duration of Ownership................................................................................ S7

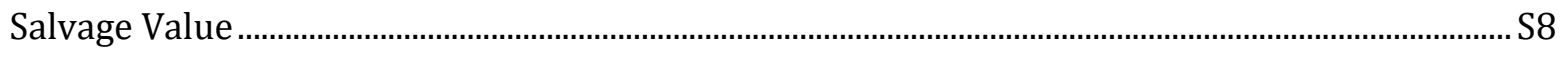

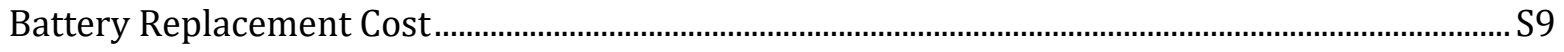

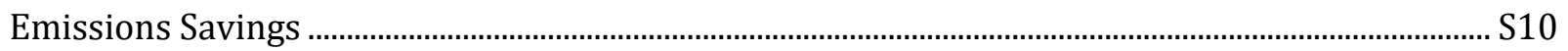

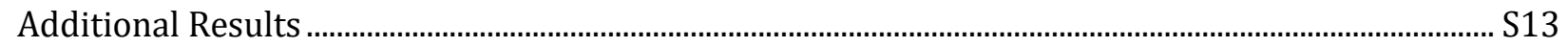

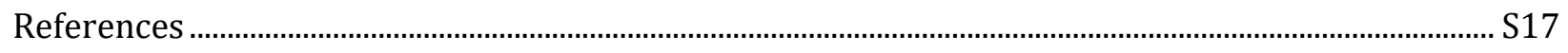




\section{Methods}

We primarily use the National Household Travel Survey (NHTS) vehicle fleet as the main input for our vehicle-level analysis. The NHTS collects vehicle attributes and use characteristics for households in the national sample. The detailed methodological framework is shown in Error! Reference source not found. of the main text. To calculate marginal abatement cost of each electric technology vehicle (HEV or BEV or PHEV), we need total cost of ownership (indicated by Equation 1 in the main text) of an ETV and the amount of emissions saved by a particular ETV. To determine the total cost of ownership we need initial capital cost. The calculations for initial capital costs are dependent on the vehicle's type of propulsion technology (electric vs. plug-in hybrid), class (Sedan vs SUV), make and model (Honda vs Toyota and Civic vs Camry). The dataset includes households' state of residence, used in indicating the resolution of geographical heterogeneity, i.e. determine state-specific electricity emissions, and fuel and electricity prices. The information about the intensity of vehicle use and the lifetime of a particular vehicle is a source of behavioral heterogeneity. The vehicles differ from each other in terms of make, model, and type of a vehicle (source of stock heterogeneity), which we have considered in our model. The following section explains how we generate the technology variants for each vehicle class.

\section{Defining Consumer Vehicle Options for Internal Combustion Engine and Electric} Technology Vehicles

The NHTS dataset contains information on the make, model and type of each vehicle in the sampled vehicle fleet. We use this information to estimate the initial capital cost and mileage. If consumers decide to switch and adopt a more energy efficient vehicle, assuming the consumers stay consistent, meaning the consumers stick to their current class type, make and model, they face four options: 1. Latest Conventional Vehicle, 2. Hybrid Engine Vehicle, 3. Battery Electric Vehicle and 4. Plug-in Hybrid Electric Vehicle. Currently, in the market, we do not have hybrid, battery electric and plug-in hybrid technology variants for every vehicle type, make and model in the NHTS vehicle fleet. For example, we do not have a battery electric truck or a battery electric Dodge Charger available in the real-world market. Therefore, we calculate the cost of the technology in addition to the price of its conventional variant. For example, in case of Dodge Charger, we calculate how much additional amount a particular consumer has to pay in get a HEV or BEV or PHEV variant which will have a comparable performance as that of a sedan (as Dodge Charger is a sedan).

We first identify make, model and fuel type of each vehicle in the dataset. For miles per gallon (or fuel efficiency), we have compiled a list of highest selling vehicles in the U.S. (added in the supplementary Excel sheet) with respect to vehicle types (Car, Van/Minivan, SUV, Truck) ${ }^{1}$. This list has the number of units sold for a particular vehicle make and model for 2017. The detailed vehicle list is attached in the supplementary information Excel sheet. The recent fuel efficiencies (miles per gallon) for each of these vehicles are taken from the U.S. Environmental Protection Agency (EPA) ${ }^{2}$ These mileages are for new Internal Combustion Engine (ICE) vehicles. We match each NHTS observation (i.e. make and model) with its corresponding U.S. EPA rated mileage. So that we can compare the electric technology vehicles with the latest conventional vehicles. For models which are not on this EPA list of highest-selling vehicles (for example, Jaguar XF), we have assigned a generic mileage for each vehicle type which is calculated as a weighted average of the number of units sold and mileage of highest sold vehicles.

For technical specifications and performance characteristics by vehicle type-sedan, SUV, van/minivan/station wagon, pickup truck, we have also generated non-existing technology variants. The power and performance characteristics of base conventional vehicles are assumed to be similar to vehicles with high market shares-for example, Toyota Camry ${ }^{3}$, Honda CRV4, Toyota RAV45, Honda Odyssey6, Ford 1507. Error! Reference source not found. shows the technical specifications (power and battery capacity) and performance characteristics (miles per gallon or 
86 miles per charge) of the technology variants. The gasoline mileage (mpg) for hybrid and plug-in

87 hybrid are assumed to be $27.5 \%$ more efficient than the conventional versions ${ }^{8,9}$. The electric

88 mileages (miles per charge) are assumed and calculated as the average mileage for available

89 electric (3.71 miles per $\mathrm{kWh}$ ) and plug-in electric vehicles (3.14 miles per $\mathrm{kWh}$ ) in the market (the

90 calculations are shown in supplementary Excel sheet). For each vehicle class, we assume the

91 battery efficiency drops as much as their conventional counterparts fuel efficiency drops. For

92 example, if the gasoline mileage drops by $21 \%$ from a sedan (32 miles per gallon i.e. mileage of a

93 generic sedan) to an SUV (25.4 miles per gallon i.e. mileage of a generic SUV), then for electric

94 variants the electric efficiency also drops by $21 \%$ from sedan (3.71 miles per kWh) to a SUV (2.95

95 miles per $\mathrm{kWh}$ ). As the BEVs in the market have wide ranges (miles per charge or full battery

96 capacity), we have modeled two BEV versions for each vehicle type with 100- and 150-mile ranges.

97 The consumers who drive more than 150 miles daily-assumed maximum range of BEV—would

98 have only HEV and PHEV technologies available to feasibly choose from. 

Variants $^{8-11}$ (ICE: Internal Combustion Engine, HEV: Hybrid Electric Vehicle, BEV: Battery Electric

Vehicle, PHEV: Plug-in Hybrid Electric Vehicle)

\begin{tabular}{|c|c|c|c|c|c|c|c|}
\hline & & \multicolumn{4}{|c|}{ Technical Specifications } & \multicolumn{2}{|c|}{ Performance } \\
\hline Vehicle Type & Technology & $\begin{array}{c}\text { Battery } \\
\text { Capacity } \\
\text { (kWh) }\end{array}$ & $\begin{array}{c}\text { ICE } \\
\text { Power } \\
\text { (kW) }\end{array}$ & $\begin{array}{c}\text { Electric } \\
\text { Motor } \\
(\mathrm{kW})\end{array}$ & $\begin{array}{c}\text { Total } \\
\text { Power } \\
(\mathrm{kW})\end{array}$ & $\begin{array}{c}\text { Mileage } \\
\text { (miles } \\
\text { per } \\
\text { gallon) }\end{array}$ & $\begin{array}{c}\text { Range } \\
\text { (miles } \\
\text { per } \\
\text { charge or } \\
\text { full } \\
\text { battery } \\
\text { capacity) }\end{array}$ \\
\hline Sedan & CONVENTIONAL & & 131 & & 131 & 34 & \\
\hline Sedan & HEV & 1 & 102 & 29 & 131 & 43 & \\
\hline $\begin{array}{l}\text { Sedan (Short } \\
\text { Range) }\end{array}$ & BEV-100 & 27 & & 131 & 131 & & 100 \\
\hline $\begin{array}{l}\text { Sedan (Long } \\
\text { Range) }\end{array}$ & BEV-150 & 40 & & 131 & 131 & & 150 \\
\hline Sedan & PHEV-40 & 13 & 85 & 46 & 131 & 43 & 40 \\
\hline SUV & CONVENTIONAL & & 142 & & 142 & 30 & \\
\hline SUV & HEV & 1.5 & 111 & 31 & 142 & 38 & \\
\hline $\begin{array}{l}\text { SUV (Short } \\
\text { Range) }\end{array}$ & BEV-100 & 34 & & 142 & 142 & & 100 \\
\hline $\begin{array}{l}\text { SUV (Long } \\
\text { Range) } \\
\end{array}$ & BEV-150 & 51 & & 142 & 142 & & 150 \\
\hline SUV & PHEV-40 & 16 & 92 & 50 & 142 & 38 & 40 \\
\hline Van/Minivan & CONVENTIONAL & & 209 & & 209 & 22 & \\
\hline Van/Minivan & $\mathrm{HEV}$ & 1.5 & 163 & 46 & 209 & 28 & \\
\hline $\begin{array}{l}\text { Van/Minivan } \\
\text { (Short Range) }\end{array}$ & BEV-100 & 40 & & 209 & 209 & & 100 \\
\hline $\begin{array}{l}\text { Van/Minivan } \\
\text { (Long Range) }\end{array}$ & BEV-150 & 60 & & 209 & 209 & & 150 \\
\hline Van/Minivan & PHEV-40 & 19 & 136 & 73 & 209 & 28 & 40 \\
\hline Truck & CONVENTIONAL & & 243 & & 243 & 18 & \\
\hline Truck & HEV & 1.5 & 190 & 53 & 243 & 23 & \\
\hline $\begin{array}{l}\text { Truck (Short } \\
\text { Range) } \\
\end{array}$ & BEV-100 & 42 & & 243 & 243 & & 100 \\
\hline $\begin{array}{l}\text { Truck (Long } \\
\text { Range) }\end{array}$ & BEV-150 & 62 & & 243 & 243 & & 150 \\
\hline Truck & PHEV-40 & 20 & 158 & 85 & 243 & 23 & 40 \\
\hline
\end{tabular}
(TCO, shown in Equation 1 in the main text). The TCO contains initial capital cost, discounted fuel 
109 For BEVs and PHEVs, the initial capital cost includes battery price as well as other electric vehicle 110 (EV) systems such as electric motor, transmission and integration, control unit, onboard charging unit, regenerative breaking, and wiring as well as credits for removing mechanical components of internal combustion engines. The battery cost and electric motor costs are scaled with respect to the battery size and power requirements for each vehicle type. The battery pack cost is calculated using the International Council on Clean Transportation (ICCT) report ${ }^{12}$, and is used to calculate the total battery cost (as shown in Equation S1). However, we have assumed $\$ 230$ per $\mathrm{kWh}$ as the battery cell price. This price is in line with various estimates for the year 2018 from previous studies ${ }^{13-15}$ and reports such as Bloomberg New Energy Finance (BNEF) ${ }^{16}$ and the Joint Technical Support Document from the U.S. Environmental Protection Agency (US-EPA) ${ }^{17}$.

Total Battery Cost (\$)

$$
=\$ 2010+\text { Battery Capacity }(k W h) \times \$ 230 \text { per } k W h
$$

Equation $S 1$

119 HEVs have similar components as that of PHEVs except for the onboard charging unit and the costs 120 of battery and electric motor are lower. The initial capital costs are, thus, calculated as additional costs of the technology over a similar conventional internal combustion engine vehicle. The cost model is build using a Massachusetts Institute of Technology report 8,9 and a National Research Council report 10,11. In addition to the costs of components, the industry markup factor of 1.46 is assumed for all vehicles ${ }^{18}$. 
Table S2 Total Incremental Cost for the Non-existing Technology Variants with Technical Specifications as shown in Table S1

\begin{tabular}{|c|c|c|c|c|c|c|c|c|c|c|c|c|}
\hline $\begin{array}{l}\text { Vehicle } \\
\text { Type }\end{array}$ & Technology & $\begin{array}{c}\text { Total } \\
\text { Battery } \\
\text { Cost }(\$)\end{array}$ & $\begin{array}{l}\text { Total } \\
\text { Motor } \\
\text { System } \\
\text { Cost } \\
(\$)\end{array}$ & $\begin{array}{l}\text { Other } \\
\text { EV } \\
\text { Systems } \\
\text { (\$) }\end{array}$ & $\begin{array}{c}\text { Hybrid } \\
\text { transmission } \\
\text { and } \\
\text { Integration } \\
(\$)\end{array}$ & $\begin{array}{c}\text { Wiring } \\
(\$)\end{array}$ & $\begin{array}{c}\text { EV } \\
\text { Transmission } \\
(\$)\end{array}$ & $\begin{array}{l}\text { ICE engine } \\
\text { credit (\$) for } \\
\text { conventional } \\
\text { starter and } \\
\text { alternator }\end{array}$ & $\begin{array}{l}\text { ICE Credit } \\
\text { (\$) for } \\
\text { downsizing }\end{array}$ & $\begin{array}{l}\text { ICE } \\
\text { Credit } \\
(\$)\end{array}$ & $\begin{array}{c}\text { Total } \\
\text { Cost }(\$)\end{array}$ & $\begin{array}{l}\text { With } \\
\text { Markup } \\
\text { Factor } \\
(\$)\end{array}$ \\
\hline Sedan & CONVENTIONAL & & & & & & & & & & & \\
\hline Sedan & HEV & 2250 & 1070 & 500 & 360 & 250 & & -120 & -140 & & 4150 & 6060 \\
\hline $\begin{array}{l}\text { Sedan (Short } \\
\text { Range) }\end{array}$ & BEV-100 & 8300 & 3520 & 950 & & 250 & 350 & & & -3890 & 9390 & 13700 \\
\hline $\begin{array}{l}\text { Sedan (Long } \\
\text { Range) }\end{array}$ & BEV-150 & 11450 & 3520 & 950 & & 250 & 350 & & & -3890 & 12380 & 18070 \\
\hline Sedan & PHEV-40 & 4500 & 1320 & 950 & 360 & 250 & & -120 & -280 & & 7470 & 10900 \\
\hline SUV & CONVENTIONAL & & & & & & & & & & & \\
\hline SUV & HEV & 2350 & 1120 & 500 & 360 & 250 & & -120 & -150 & & 4310 & 6300 \\
\hline $\begin{array}{l}\text { SUV (Short } \\
\text { Range) }\end{array}$ & BEV-100 & 9800 & 3800 & 950 & & 250 & 350 & & & -4070 & 11070 & 16160 \\
\hline $\begin{array}{l}\text { SUV (Long } \\
\text { Range) }\end{array}$ & BEV-150 & 13700 & 3800 & 950 & & 250 & 350 & & & -4070 & 14970 & 21870 \\
\hline SUV & PHEV-40 & 5700 & 1400 & 950 & 360 & 250 & & -120 & -300 & & 8250 & 12040 \\
\hline Van/Minivan & CONVENTIONAL & & & & & & & & & & & \\
\hline Van/Minivan & HEV & 2350 & 1480 & 500 & 360 & 250 & & -120 & -220 & & 4600 & 6710 \\
\hline $\begin{array}{l}\text { Van/Minivan } \\
\text { (Short } \\
\text { Range) } \\
\end{array}$ & BEV-100 & 11300 & 5500 & 950 & & 250 & 350 & & & -4940 & 13380 & 19530 \\
\hline $\begin{array}{l}\text { Van/Minivan } \\
\text { (Long Range) }\end{array}$ & BEV-150 & 16000 & 5500 & 950 & & 250 & 350 & & & -4940 & 18000 & 26300 \\
\hline Van/Minivan & PHEV-40 & 6400 & 2020 & 950 & 360 & 250 & & -120 & -440 & & 9400 & 13720 \\
\hline Truck & CONVENTIONAL & & & & & & & & & & & \\
\hline Truck & HEV & 2350 & 1700 & 500 & 360 & 250 & & -120 & -260 & & 4150 & 6060 \\
\hline $\begin{array}{l}\text { Truck (Short } \\
\text { Range) }\end{array}$ & BEV-100 & 11600 & 6400 & 950 & & 250 & 350 & & & -6030 & 9390 & 13700 \\
\hline $\begin{array}{l}\text { Truck (Long } \\
\text { Range) }\end{array}$ & BEV-150 & 16300 & 6400 & 950 & & 250 & 350 & & & -6030 & 12380 & 18070 \\
\hline Truck & PHEV-40 & 6530 & 2300 & 950 & 360 & 250 & & -120 & -510 & & 7470 & 10900 \\
\hline
\end{tabular}




\section{Calculation of Expected Duration of Ownership}

After the initial capital cost, we calculate the expected duration of ownership. A lifetime of a vehicle differs from the expected duration of ownership because different consumers use their vehicles for a different number of years before switching and/or selling vehicles. The NHTS provides the number of months a vehicle owned. We use these observed durations to generate a distribution for how long owners have currently owned their vehicle. This duration differs from the actual duration of ownership before vehicle disposal or retirement.

The survival rate is calculated for each year i.e. the percentage of vehicles using their vehicle past the respective year, conditional upon the consumers have used their vehicles until that year (i.e. how long they have currently owned their vehicle).

The survivor function is shown in Equation S2, $n_{j}$ is the number of consumers using their vehicles past duration $t_{j}$, and $h_{j}$ is the number of consumers who sold their vehicles in the duration $t_{j}$. It is estimated by setting the estimated conditional probability of using the vehicle past $t_{j}$ equal to the observed relative frequency of completion at $t_{j}$. The distribution is shown in Figure S1 and it depicts how frequently the consumers replace their vehicles.

$$
\hat{S}\left(t_{j}\right)=\prod_{j=1}^{j}\left(n_{j}-h_{j}\right) / n_{j}
$$

Equation 52

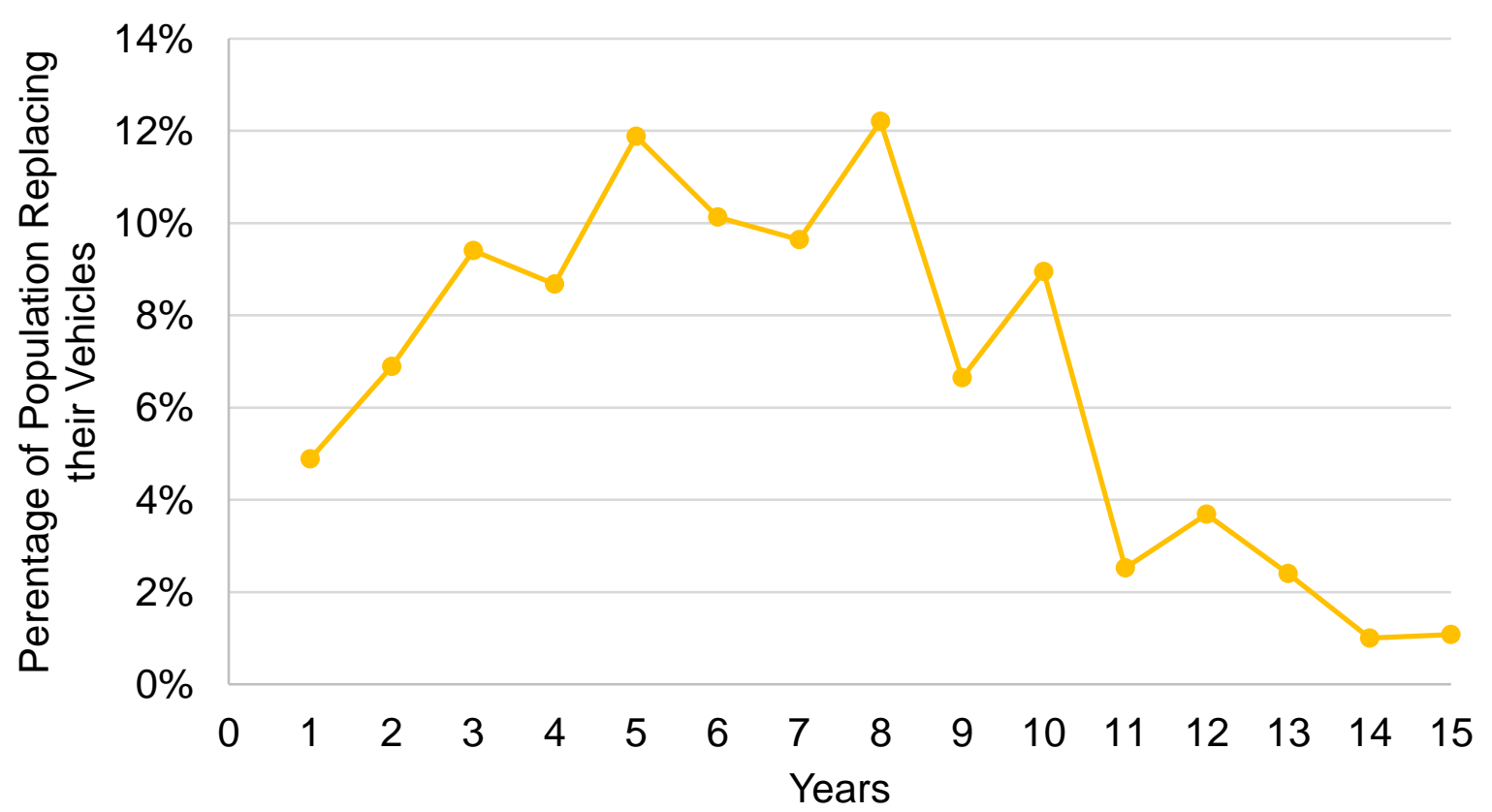

Figure S1 Distribution of Population Replacing their Vehicles in respective years

To calculate the expected duration of ownership ( $n$ ), given a consumer has used their vehicle for ' $x$ ' number of years, we build the new distribution with the remaining probabilities by determining the 
conditional survival probability given that the vehicle own year (currently owned duration) is not complete, assuming the maximum lifetime is assumed to be fifteen years.

Salvage Value

The Salvage Value is a value of a vehicle in a used car market at the end of the expected duration of ownership. It is estimated as a function of years of ownership. R. Raustad has generated an equation to estimate depreciation percentage (is shown in Figure S2) as a function (With $\mathrm{R}^{2}=0.9997$ ) of years of ownership of the vehicles ${ }^{19}$. The author has collected data from Edmunds.com for several makes and models. The equation to calculate the depreciation percentage is as shown in Equation S3. The consumer receives the salvage value at the end of expected duration of ownership $(n)$, therefore, we have accounted it as the present value of future money, as shown in Equation S5.

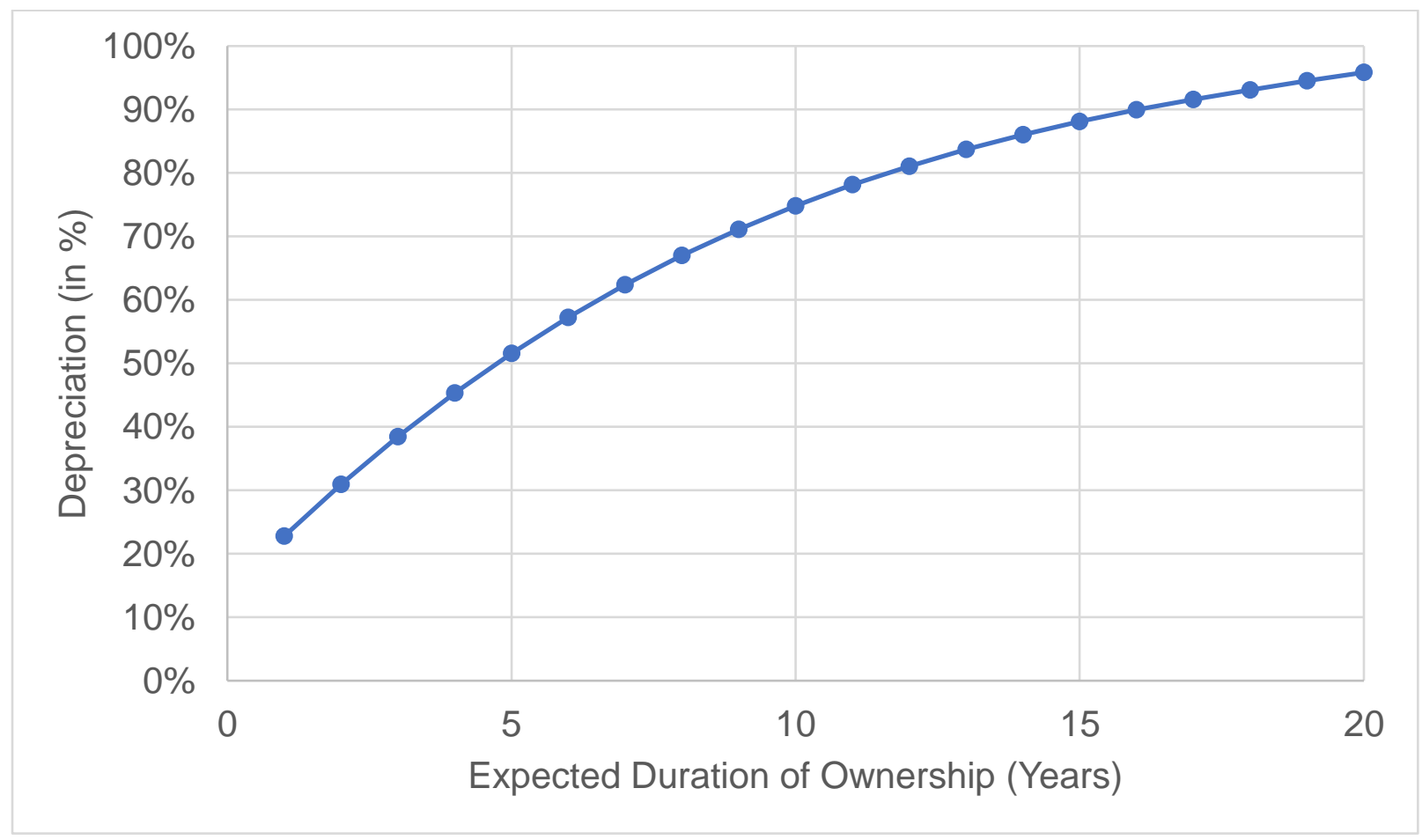

Figure S2 Depreciation Percentage at a function of Expected Duration of Ownership (Years)

Depreciation Percentage $=\left(6 \times 10^{-5}\right) n^{3}-(0.0038) n^{2}+(0.093) n+0.1384 \quad$ Equation $S 3$

Salvage Value of a vehicle (\$)

$=$ Depreciation Percentage $\times$ Initial Capital Cost $(\$)$

Equation $S 4$

Discounted Salvage Value at the end of duration of ownership

$=$ Salvage Value of a vehicle $\times(1+r)^{-n}$

Equation S5 


\section{Battery Replacement Cost}

For BEVs and PHEVs, a battery replacement cost at the end of life, and life of the battery is estimated as a function of number of charging-discharging cycles and depth of discharge ${ }^{19,20}$. The battery lifetime is calculated as shown in Equation S6 and Equation S7Error! Reference source not found.. E. Wood et al. calculated the power level of $70 \%$ of the peak power can be achieved with the depth of discharge of $80 \%$ and charging-discharging cycles of 3,500 20 . Therefore, to calculate battery lifetime, we assume the depth of discharge $80 \%$, and 3,500 charging-discharging cycles. Thus, for example, the battery of $27 \mathrm{kWh}$ with efficiency 3.71 miles per $\mathrm{kWh}$, depth of discharge $80 \%$, and 3,500 charging-discharging cycles can provide 280,476 miles in its lifetime, and with 18,000 annual miles, the battery life would be 15.6 years. However, battery replacement costs were considered only if the battery life was equal to or less than 15 years (the assumed maximum life of the vehicle). Using this battery lifetime, the discounted battery replacement cost is calculated. For the consumers who have battery lifetime more than the expected duration of ownership, and when these consumers sell their vehicles and the buyer of this used vehicle would need to replace the degraded battery shortly after. Therefore, to compensate for this battery use, we consider that the previous owner still pays for the battery replacement. To account for this cost, we reduce the discounted salvage value by the amount the consumer would have paid to replace the battery by saving annually until the end of the expected duration of ownership.

$$
\begin{aligned}
& \text { Maximum Miles in battery's lifetime }(\text { miles }) \\
& \quad=\text { Battery Capacity }(k W h) \\
& \times \text { Battery Efficiency }(\text { miles per } k W h) \\
& \times \text { Depth of Discharge }(80 \%) \\
& \times \text { No.of Charging Discharging Cycles }(3500)
\end{aligned}
$$

Equation S6

$$
\text { Battery Lifetime }(\text { years })=\frac{\text { Maximum Miles in battery's lifetime }}{\text { Annual Miles }}
$$

Equation 57

Finally, we calculate the discounted fuel savings. The first step of calculating the fuel savings is to identify the fuel and electricity costs for each consumer. Using the household's State of residency, each observation is assigned electricity emissions per kWh (of generation) from the U.S. Energy Information Agency ${ }^{21}$ as well as the conventional fuel prices ${ }^{22-24}$. As all the calculations are done in comparison with the conventional vehicle, first annual fuel costs of conventional vehicles are calculated (Equation S8). Then the fuel costs of each of the technology variant are calculated for each vehicle type. The fuel costs for HEVs are calculated like that of a conventional vehicle (Equation S9). For BEVs, first the annual electricity consumption is calculated using the maximum range of the vehicle and then the cost of electricity consumption (i.e. the fuel cost) is calculated (Equation S10). For PHEVs, the fuel costs are calculated similar to that of BEVs, and it is assumed that the consumer first uses the electric energy and once the battery runs out (i.e. maximum range of PHEV) the vehicle is run on gasoline (Equation S11). The annual fuel savings are calculated for each of the technology variants (Equation S12) and then converted to discounted fuel savings (present value of annuity) for the total expected duration of ownership (Equation S13). All these cost components are discounted at an assumed discount rate $(r)$ of $7 \%$. For each consumer, we select the least total cost to the consumers (i.e. the highest Net Present Value) electric technology vehicle. The annualized Costs are shown in Error! Reference source not found. as negative annualized Net Present Value. 
Fuel Cost for Conventional Vehicles (\$)

$$
=\frac{\text { Annual Miles }}{\text { Mileage }(\text { miles per gallon })} \times \text { Fuel Price }(\$ / \text { gallon })
$$

Equation S8

Fuel Cost for HEVs $(\$)=\frac{\text { Annual Miles }}{\text { Mileage }(\text { miles per gallon })} \times$ Fuel Price $(\$ /$ gallon $) \quad$ Equation S9

Fuel Cost for BEVs $(\$)$

$$
=\frac{\text { Annual Miles }}{\text { Electric Mileage }(\text { miles per } k W h)} \times \text { Fuel Price }(\$ / k W h)
$$

Equation $S 10$

Fuel Cost for PHEVs (\$)

$$
=\left[\begin{array}{c}
\frac{\text { Range of PHEV (miles) }}{\text { Electric Mileage }(\text { miles per } \mathrm{kWh})} \times \text { Fuel Price }(\$ / \mathrm{kWh}) \\
+\frac{(\text { Annual Miles } / 365-\text { Range of } P H E V)}{\text { Mileage }(\text { miles per gallon })} \times \text { Fuel Price }(\$ / \text { gallon })
\end{array}\right] \times 365
$$

Equation S11

Annual Fuel Savings (\$)

$$
\text { = Fuel Cost of conventional vehicles }(\$)
$$

Equation $S 12$

- Fuel Cost of Electric Technology Vehicle(\$)

Discounted Fuel Savings $(\$)=$ Annual Fuel Savings $\times\left[\frac{1-(1+r)^{-n}}{r}\right]$

Equation $S 13$

\section{Emissions Savings}

After selecting the least total cost to the consumer technology (or a preferred technology), we calculate the annual emissions saved by the respective electric technology vehicle. For conventional vehicles and HEVs, the emissions saved are calculated using the amount of fuel consumed (Equation S14-Equation S15).

Emissions for conventional vehicle $\left(\mathrm{kgCO}_{2} \mathrm{e}\right)$

$$
\begin{aligned}
& =\frac{\text { Annual Miles }}{\text { Mileage (miles pergallon) }} \\
& \times \text { Emissions per gallon }\left(\mathrm{kgCO}_{2} \text { e } / \text { gallon of fuel }\right)
\end{aligned}
$$




$$
\begin{aligned}
\text { Emissions for } & \mathrm{HEV}\left(\mathrm{kgCO}_{2} \mathrm{e}\right) \\
& =\frac{\text { Annual Miles }}{\text { Mileage }_{\mathrm{HEV}}(\text { miles pergallon })} \\
& \times \text { Emissions per gallon }\left(\mathrm{kgCO}_{2} \mathrm{e} / \text { gallon of fuel }\right)
\end{aligned}
$$

To calculate emissions savings from BEVs and PHEVs, we first assign emissions for generating 1 $\mathrm{kWh}$ of electricity to each observation as per the household state. The electricity emissions are sourced from marginal emission factors ( $\mathrm{MEF}$ in $\mathrm{kgCO}_{2} \mathrm{e} / \mathrm{kWh}$ ) for electricity generation for each state are used from the latest updated work of Azevedo et al. 201725. For BEVs, the electric efficiency (miles per $\mathrm{kWh}$ ) and annual miles driven are used to calculate the annual electricity consumption. Then using the electricity emissions $\left(\mathrm{kgCO}_{2}\right.$ e per $\left.\mathrm{kWh}\right)$ for generating $1 \mathrm{kWh}$ in the respective state-assuming the consumers charge their vehicle in the state of their residence-are used to calculate the total annual emissions (Equation S16).

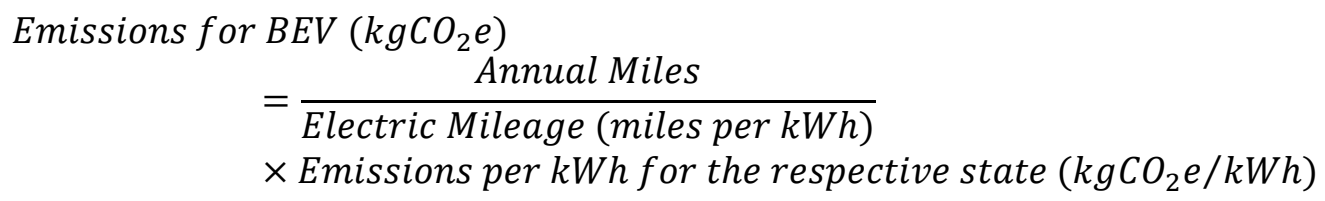

Equation S16

For PHEVs, the emissions from electricity consumption are calculated in a similar fashion as that of BEVs. The emissions from gasoline consumption are calculated similar to that of HEVs, as shown in Equation S17. First using the battery range (as we assume consumers will use PHEVs on electricity first), we calculate the electricity consumption, followed by the emissions from electricity consumption. As the remaining daily miles are expected to be driven using gasoline, the rest of the emissions are calculated for consuming gasoline.

$$
\begin{aligned}
& \text { Emissions for PHEV }\left(\mathrm{kgCO}_{2} \mathrm{e}\right) \\
& =\left[\begin{array}{c}
\frac{\text { Range of } \mathrm{PHEV}(\text { miles })}{\text { Electric Mileage }(\text { miles per } \mathrm{kWh})} \times\left(\frac{\mathrm{kgCO} \mathrm{C}_{2} \mathrm{e}}{\mathrm{kWh}}\right)_{\text {for respective state }} \\
+\frac{(\text { Annual Miles } / 365-\text { Range of } \mathrm{PHEV})}{\text { Mileage } \mathrm{PHEV}_{\mathrm{PH}}(\text { miles per gallon })} \times\left(\mathrm{kgCO}_{2} \text { e/gallon of fuel }\right)
\end{array}\right] \times 365
\end{aligned}
$$

In addition to emissions from operation phase, we have included Well-To-Pump (WTP) emissions (in terms of $\mathrm{gCO}_{2} / \mathrm{mile}$ ) for each vehicle type and each powertrain from the GREET (Greenhouse gases, Regulated Emissions, and Energy use in Transportation) model developed by Argonne National Laboratory ${ }^{26}$. Emissions $\left(\mathrm{gCO}_{2} / \mathrm{mile}\right)$ for the vehicles are attached in the SI excel sheet. Apart from use phase (tailpipe) and lifecycle emissions we use upstream fuel emissions from vehicles. We use average upstream emissions for gasoline $\left(2,400 \mathrm{gCO}_{2} /\right.$ gallon $)$ and electricity $(72.5$ $\mathrm{gCO}_{2} / \mathrm{kWh}$ ) from Yuksel et al. $2016^{27}$ who used other studies to estimate these emission factors ${ }^{26-29}$.

The annual fuel savings are calculated using the emissions of conventional vehicle and emissions from an Electric Technology Vehicle. For the preferred technology then we calculate the total emissions saved over the expected duration of ownership. 


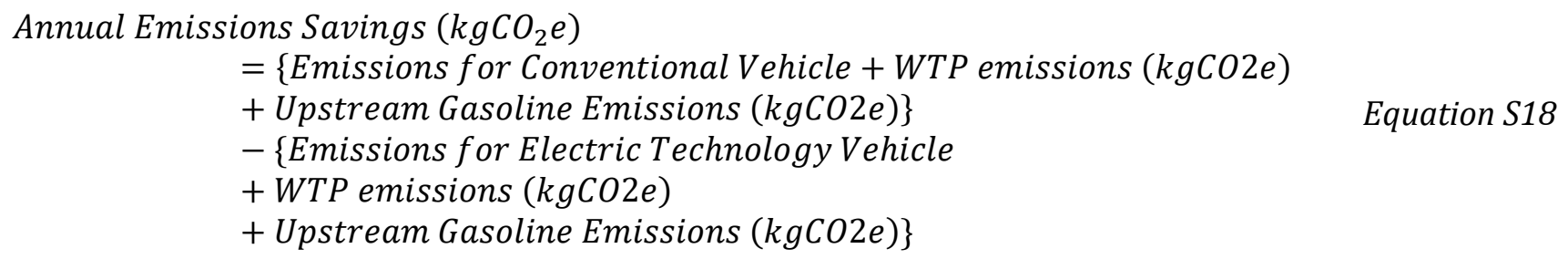

To calculate carbon marginal abatement costs, we use the Total Cost of Ownership and the Total Emissions Saved over the expected duration of ownership.

The carbon marginal abatement costs (US\$ per $\mathrm{MTCO}_{2} \mathrm{e}$, shown in Equation S19) are calculated for the preferred technology options.

$$
\begin{aligned}
& \text { Carbon Marginal Abatement Cost }\left(\mathrm{US} \$ / \mathrm{MT} \mathrm{CO}_{2} e\right) \\
& =\frac{\text { Total discounted cost of a technology }(\mathrm{US} \$)}{\text { Total emissions savings by the respective technology }\left(\mathrm{MT} \mathrm{CO}_{2} e\right)}
\end{aligned}
$$




\section{Additional Results}

In this section we present results for marginal abatement cost curves that account only for operational emissions of vehicles, i.e. neglecting vehicle manufacturing and upstream fuel production as presented in the main text.

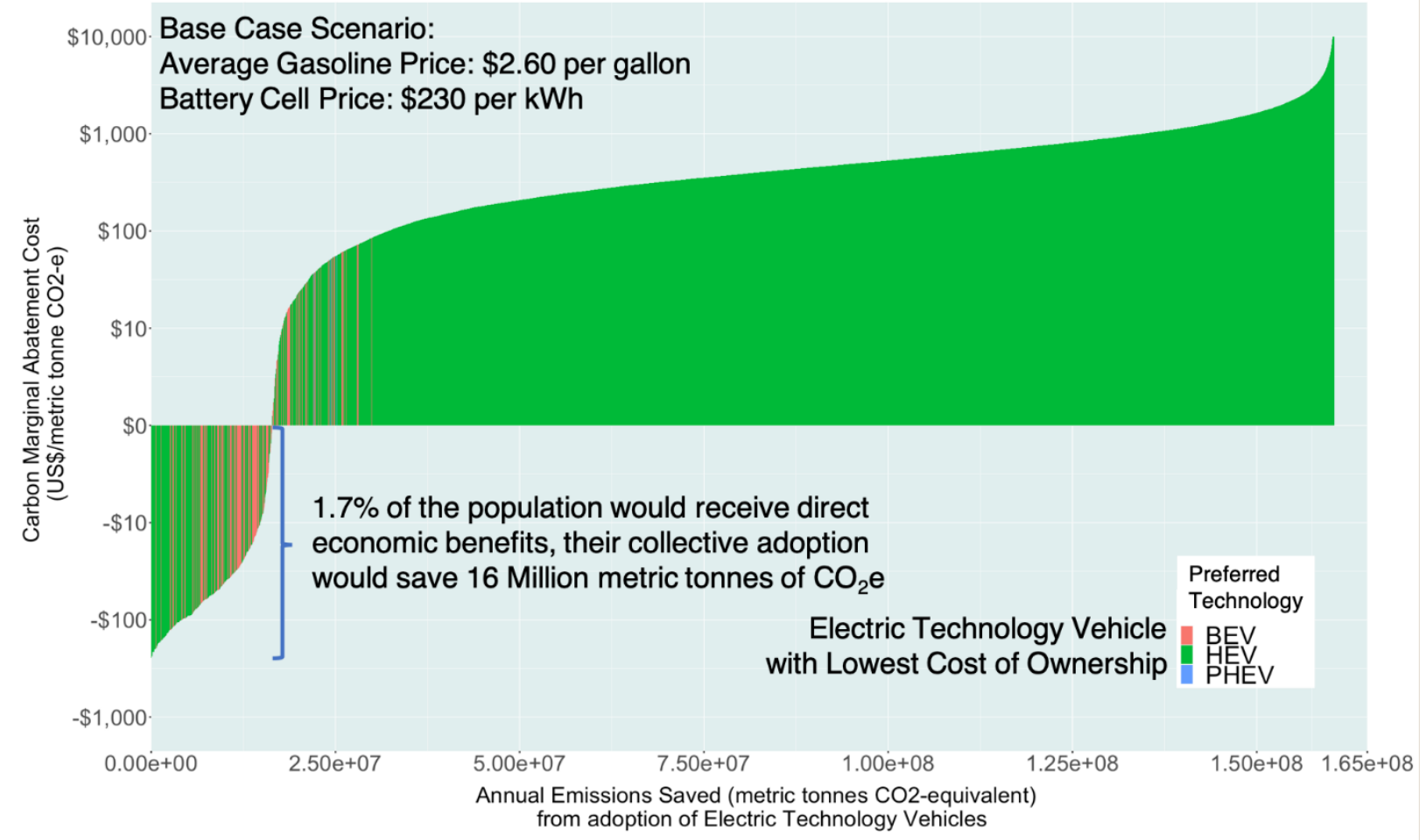

Figure S3 Carbon Marginal Abatement Cost Curve (MACC) for electric technology vehicles (ETV) with current prices and no subsidy (OPERATION/USE PHASE ONLY). The figure shows a series of narrow rectangles, ordered from lowest to highest height, with log scale. Each rectangle height is the cost of abatement of one metric tonnes (MT) of $\mathrm{CO}_{2}$ e for a response from the National Household Travel Survey. Negative marginal cost represents consumers who financially benefit (save money) from buying an electric technology vehicle. The width of each rectangle is the amount of carbon emissions saved in a year from this household class switching to its least cost electric technology vehicle, the total width reflects every personal vehicle in the U.S. being replaced by an ETV. Note that this base case scenario does not account for current federal tax credits for PHEV and EV of up to US\$7,500 or state/local subsidies. (BEV: Battery Electric Vehicle, HEV: Hybrid Electric Vehicle, PHEV: Plug-in Hybrid Electric Vehicle).

Similar to the base case scenario a relatively small population, $1.7 \%$ of all drivers, benefits economically from electric technology vehicles, mainly hybrids. The estimated 'free carbon' in the base case scenario is 20 Million Metric Tonnes (MMT) $\mathrm{CO}_{2} \mathrm{e}$. The consumers who directly benefit financially have an average carbon abatement cost of $-\$ 56$ per $\mathrm{MTCO}_{2} \mathrm{e}$ as compared to $\$ 45$ per $\mathrm{MTCO}_{2} \mathrm{e}$ for base case scenario. 


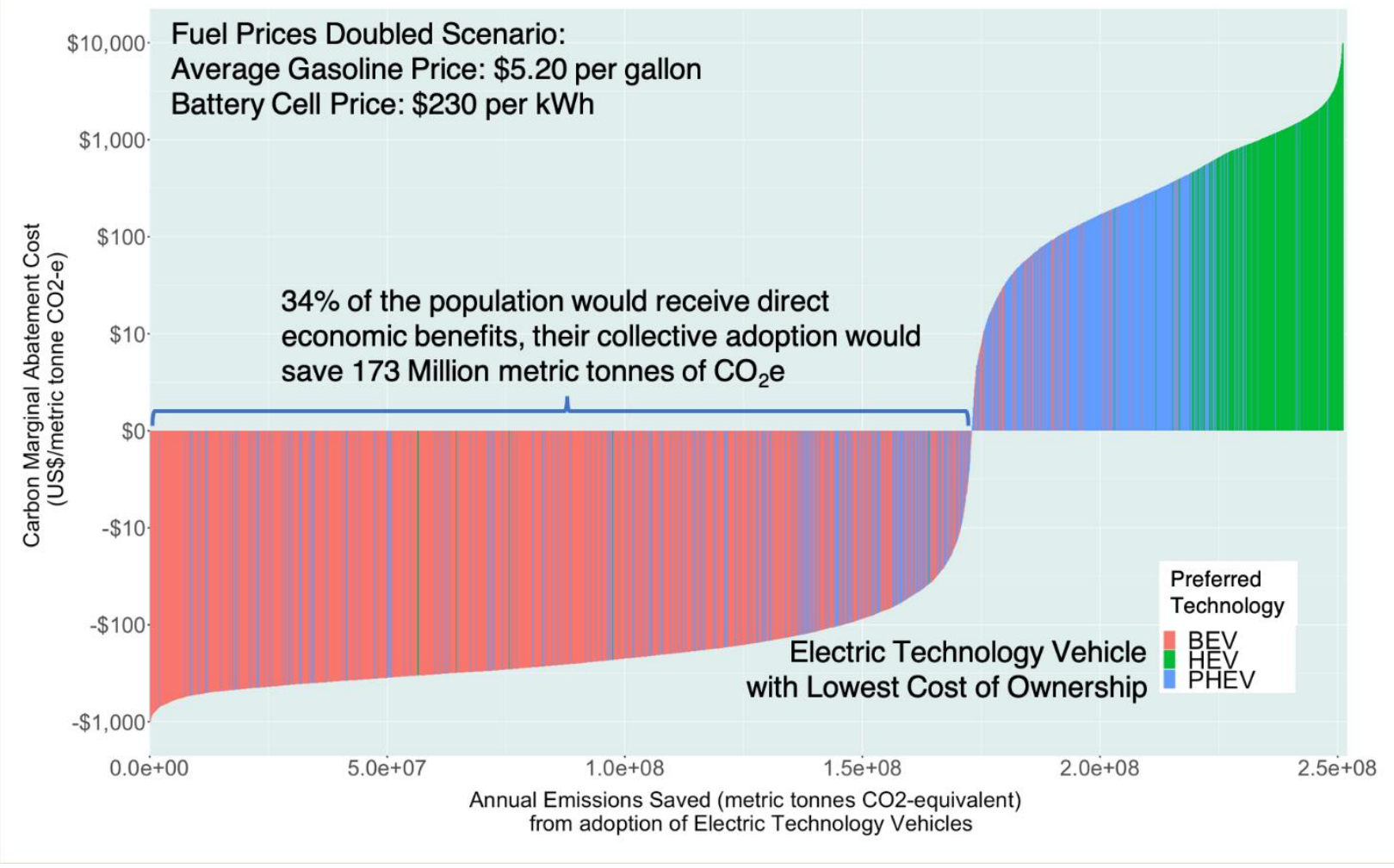

Figure S4 Carbon Marginal Abatement Cost Curve (MACC) for electric technology vehicles (ETVs) with doubled gasoline price ( $\$ 5.20$ per gallon) and current vehicle prices. $34 \%$ of the population saves money (negative abatement cost) from ETVs, their adoption would yield 173 Million Metric Tonnes (MMT) of $\mathrm{CO}_{2}$ e of "Free Carbon", considering OPERATION/USE PHASE ONLY. The consumers who directly benefit financially have an average carbon abatement cost of - $\$ 240$ per $\mathrm{MTCO}_{2}$ e (BEV: Battery Electric Vehicle, HEV: Hybrid Electric Vehicle, PHEV: Plug-in Hybrid Electric Vehicle). 


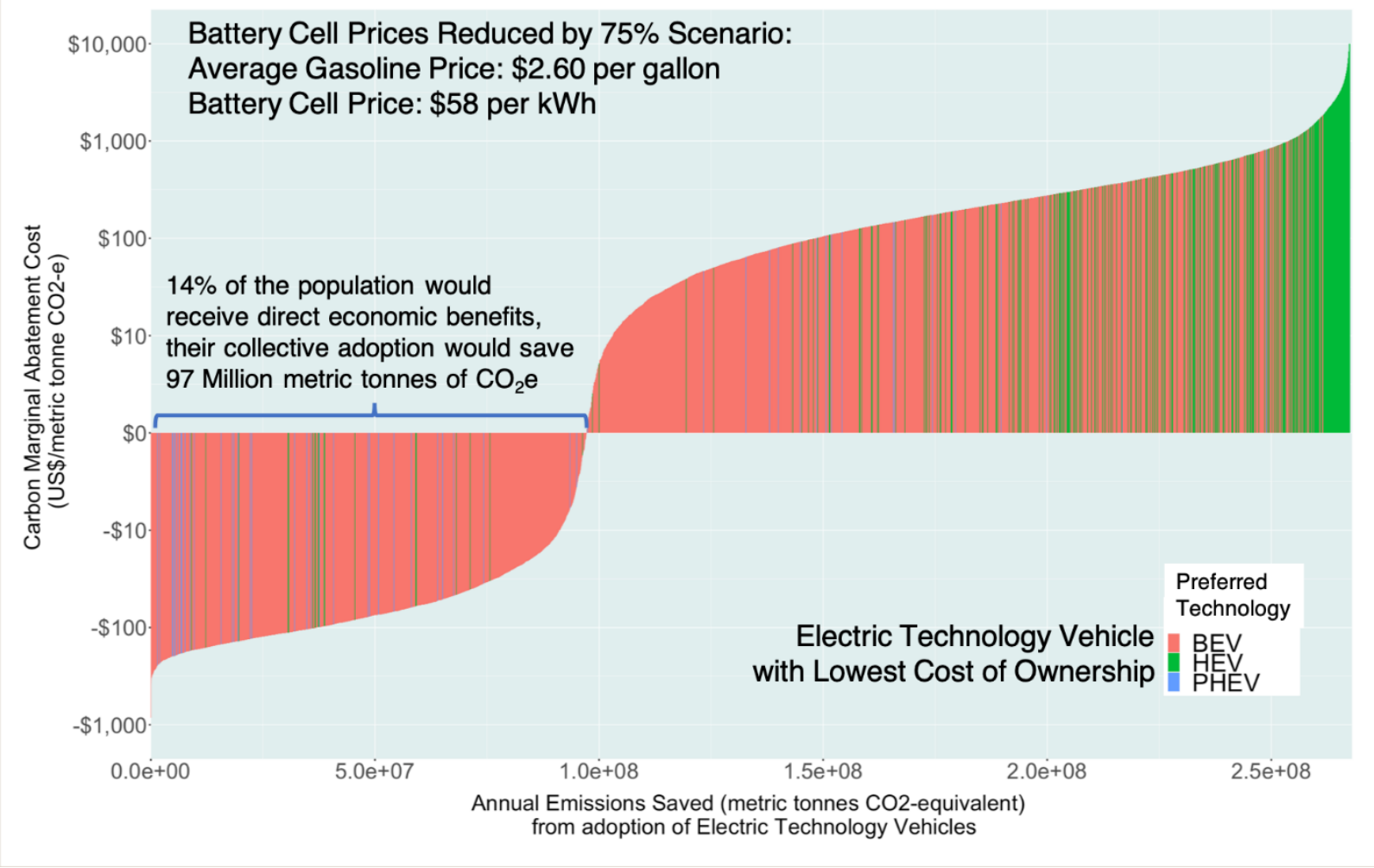

Figure S5 Carbon Marginal Abatement Cost Curve (MACC) for electric technology vehicles (ETVs) with current gasoline price and battery cell cost of $\$ 58$ per $k W h$ (25\% of the current battery cell prices of $\$ 230$ per $k W h$ ). Adoption by the $14 \%$ of population that benefits financially (negative abatement cost), their adoption would yield 97 Million Metric Tonnes (MMT) of $\mathrm{CO}_{2} e$ of "Free Carbon", considering OPERATION/USE PHASE ONLY. The consumers who directly benefit financially have an average carbon abatement cost of -\$78 per $\mathrm{MTCO}_{2}$ e. (BEV: Battery Electric Vehicle, HEV: Hybrid Electric Vehicle, PHEV: Plug-in Hybrid Electric Vehicle) 


\section{Sensitivity Analysis for interest rates}

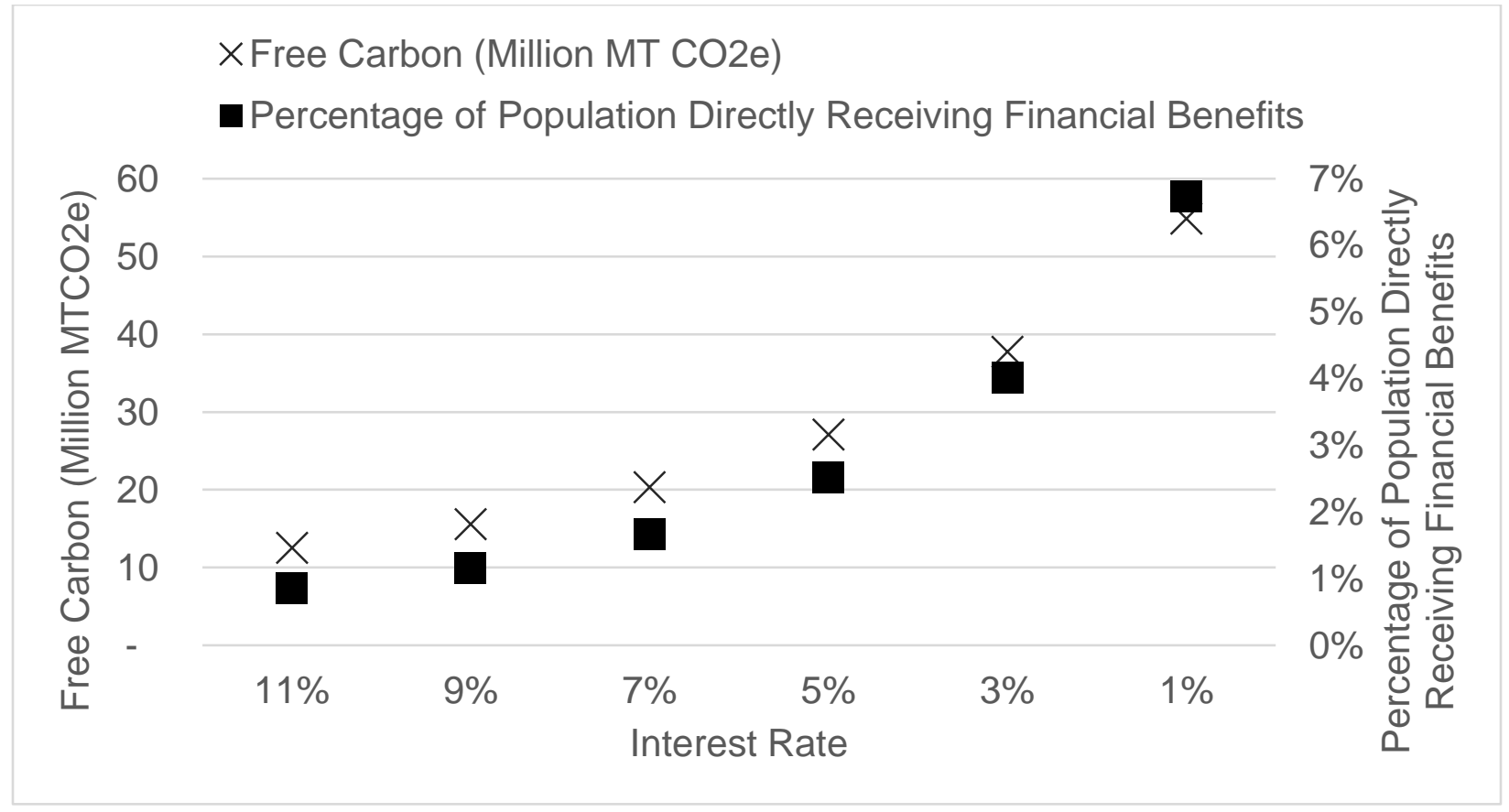

Figure S6 Impact of Interest Rate (\%) on Free Carbon (Million $\mathrm{MTCO}_{2} \mathrm{e}$ ) and corresponding percentage of population directly receiving financial benefits. Interest rate of $7 \%$ denotes the Base Case Scenario in the main text. 


\section{References}

(1) GoodCarBadCar.net. Auto Sales Data | Canada \& the USA | GoodCarBadCar.net http://www.goodcarbadcar.net/ (accessed Jan 1, 2018).

(2) U.S.-EPA. Fuel Economy https://www.fueleconomy.gov/ (accessed Feb 27, 2018).

(3) Toyota. Toyota Camry:ebrochure.

(4) Honda. Honda CRV:Specifications.

(5) Toyota. Toyota RAV4:Specifications.

(6) Honda. Honda Odyssey:Specifications.

(7) Ford. Fond 150:Specifications.

(8) Kromer, M. A.; Heywood, J. B. Electric Powertrains: Opportunities and Challenges in the U.S. Light-Duty Vehicle Fleet; Cambridge, Massachusetts, 2007.

(9) Kromer, M. A.; Heywood, J. B. Electric Powertrains : Opportunities and Challenges in the U.S. Light-Duty Vehicle Fleet; Cambridge, Massachusetts, 2007. https://doi.org/LFEE 2007-03 RP.

(10) N.R.C. Transitions to Alternative Vehicles and Fuels; Washington, D.C., 2013. https://doi.org/10.17226/18264.

(11) N.R.C. Transitions to Alternative Vehicles and Fuels: Appendix F; Washington, D.C., 2013.

(12) Wolfram, A. P.; Lutsey, N. Electric Vehicles: Literature Review of Technology Costs and Carbon Emissions; Washington, D.C., 2016.

(13) Nykvist, B.; Nilsson, M. Rapidly Falling Costs of Battery Packs for Electric Vehicles. Nature Climate Change 2015, 5 (4), 329-332. https://doi.org/10.1038/nclimate2564.

(14) Safari, M. Battery Electric Vehicles: Looking behind to Move Forward. Energy Policy 2018, 115 (December 2017), 54-65. https://doi.org/10.1016/j.enpol.2017.12.053.

(15) Nykvist, B.; Sprei, F.; Nilsson, M. Assessing the Progress toward Lower Priced Long Range Battery Electric Vehicles. Energy Policy 2019, 124 (September 2017), 144-155. https://doi.org/10.1016/j.enpol.2018.09.035.

(16) Curry, C. Lithium-Ion Battery Costs and Market; 2017.

(17) EPA; NHTSA. Joint Technical Support Document: Final Rulemaking for 2017-2025 Light-Duty Vehicle Greenhouse Gas Emission Standards and Corporate Average Fuel Economy Standards. Epa.Gov 2012, No. August 2012, 602. https://doi.org/10.1007/s13398-0140173-7.2.

(18) Rogozhin, A.; Gallaher, M.; Helfand, G.; McManus, W. Using Indirect Cost Multipliers to Estimate the Total Cost of Adding New Technology in the Automobile Industry. International Journal of Production Economics 2010, 124 (2), 360-368. https://doi.org/10.1016/j.ijpe.2009.11.031.

(19) Raustad, R. Electric Vehicle Life Cycle Cost Analysis; Cocoa, FL, 2017. https://doi.org/FSECCR-2053-17.

(20) Wood, E.; Alexander, M.; Bradley, T. H. Investigation of Battery End-of-Life Conditions for Plug-in Hybrid Electric Vehicles. Journal of Power Sources 2011, 196 (11), 5147-5154. 
https://doi.org/10.1016/j.jpowsour.2011.02.025.

(21) U.S.-EIA. State Electricity Profiles https://www.eia.gov/electricity/state/\%0A (accessed Jan $1,2018)$.

(22) www.AAA.com. Gas Prices http://gasprices.aaa.com/state-gas-price-averages/ (accessed Jan $1,2018)$.

(23) CNG-Now. Average CNG Price By State http://www.cngnow.com/average-cngprices/Pages/default.aspx (accessed Jan 1, 2018).

(24) GasBuddy.com. GasBuddy.com http://www.gasbuddy.com/USA (accessed Feb 13, 2018).

(25) Azevedo, I.; Horner, N.; Siler-Evans, K.; Vaishnav, P. Electricity Marginal Factors Estimates https://cedm.shinyapps.io/MarginalFactors/.

(26) ANL. GREET® Model The Greenhouse gases, Regulated Emissions, and Energy use in Transportation Model (reseased on Oct 10, 2018) https://greet.es.anl.gov.

(27) Yuksel, T.; Tamayao, M. A. M.; Hendrickson, C.; Azevedo, I. M. L.; Michalek, J. J. Effect of Regional Grid Mix, Driving Patterns and Climate on the Comparative Carbon Footprint of Gasoline and Plug-in Electric Vehicles in the United States. Environmental Research Letters 2016, 11 (4). https://doi.org/10.1088/1748-9326/11/4/044007.

(28) Venkatesh, A.; Jaramillo, P.; Griffin, W. M.; Matthews, H. S. Uncertainty Analysis of Life Cycle Greenhouse Gas Emissions from Petroleum-Based Fuels and Impacts on Low Carbon Fuel Policies. Environmental Science and Technology 2011, 45 (1), 125-131. https://doi.org/10.1021/es102498a.

(29) Tamayao, M. A. M.; Michalek, J. J.; Hendrickson, C.; Azevedo, I. M. L. Regional Variability and Uncertainty of Electric Vehicle Life Cycle CO2 Emissions across the United States.

Environmental Science and Technology 2015, 49 (14), 8844-8855.

https://doi.org/10.1021/acs.est.5b00815. 